\title{
Balloon dilatation of the aortic valve for inoperable aortic stenosis
}

\author{
David C Sprigings, Graham Jackson, John B Chambers, Mark J Monaghan, Stephen D Thomas, \\ T Brendan Meany, David E Jewitt
}

\begin{abstract}
The place of balloon dilatation of the aortic valve in the treatment of calcific aortic stenosis is controversial. Thirty two patients (mean age 76) in whom valve replacement was contraindicated were followed up for three to 24 months (mean 8); 25 were in functional class III or IV according to the New York Heart Association's classification. Major complications of the procedure occurred in four patients. Echocardiography and Doppler studies were performed before operation and before discharge in 28 patients, and the area of the valve was measured again six to 50 (mean 23) weeks after operation in 11 patients. The peak to peak aortic pressure gradient fell from a mean of 65 (SD 24) to 46 (20) $\mathrm{mm} \mathrm{Hg}$, but the area of the aortic valve, measured by Doppler echocardiography, in 18 patients showed a modest but significant increase, from $0.61(0.16)$ to $0.74(0.23) \mathrm{cm}^{2}$. One month after dilatation, 29 patients were alive, of whom 17 had improved symptoms. Only two had lasting clinical benefit. Sixteen patients died, 12 of a cardiac cause. The estimated one year survival rate was $49 \%$. Six patients underwent or required valve replacement because of persisting symptoms.

In view of its limited long term efficacy balloon dilatation of the aortic valve should be used only for patients with severe symptoms whose life expectancy is limited by other disease or who are considered to be unsuitable for valve replacement. It may have a role in improving the condition of patients who present with cardiogenic shock or pulmonary oedema before valve replacement is undertaken.
\end{abstract}

\section{Introduction}

Patients aged 70 and over form a large proportion of those with severe aortic stenosis. ${ }^{1}$ The mortality associated with elective aortic valve replacement in this age group is roughly $5 \%,,^{23}$ but that associated with emergency operation may be as high as $31 \%$. $^{3}$ Valve replacement may not be undertaken in some elderly patients (those considered to have an unacceptably high operative risk or limited life expectancy because of accompanying non-cardiac disease), but data on this have not been included in reports of surgical series.

The use of percutaneous balloon dilatation of the aortic valve to treat calcific aortic stenosis has attracted wide interest since the first report of the technique in 1986. ${ }^{4}$ Although it improves valve function and symptoms in the short term, ${ }^{5-10}$ its long term efficacy remains unclear. We report on 32 patients who were followed up for up to two years.

\section{Patients and methods}

Patients were selected for balloon dilatation of the aortic valve if calcific aortic stenosis had been con- firmed by cross sectional echocardiography, Doppler ultrasound, and measurements of intracardiac pressure; they had symptoms of angina, breathlessness, or syncope (New York Heart Association's functional classes II-IV ${ }^{11}$ ); appreciable aortic regurgitation (no more than grade $2+$ on supravalvar aortography) and left main stem coronary artery disease were absent; and one or more major contraindications to valve replacement had been agreed with a cardiac surgeon. Contraindications included advanced age and infirmity, malignancy, or other non-cardiac disease associated with an increased operative risk. One patient (a 73 year old man) had refused valve replacement.

Coronary arteriography was performed by Judkins's technique through the right femoral artery, ${ }^{12}$ followed by supravalvar aortography to assess the degree of aortic regurgitation and identify the orientation of the valve orifice. The aortic valve was crossed with a straight guide wire; an Amplatz left coronary catheter was used as a guide if necessary. Left ventricular pressure was recorded with simultaneous aortic pressure by either a catheter inserted through the left femoral artery or a long sheath in the right femoral artery.

If the aortic valve was suitable for balloon dilatation the patient was given heparin 5000 units, the right femoral artery was progressively dilated, and a 14 French gauge sheath with a haemostatic valve was inserted. The catheter balloon was introduced by an exchange guide wire (the end of which had been bent into a large $J$ to reduce the risk of perforating the ventricle) and positioned across the aortic valve.

Before the balloon was inflated atropine $1 \mathrm{mg}$ was given intravenously. The balloon was inflated by hand with a mixture of saline and contrast to the manufacturer's maximum recommended pressure (400-600 $\mathrm{kPa}$ (4-6 atmospheres)). Inflation was maintained for 10-15 seconds and aortic pressure monitored continuously. Although other workers have used longer periods of inflation, ${ }^{67}$ we found that inflation for longer than 15 seconds often resulted in a substantial fall in aortic pressure, which required an infusion of dopamine. Usually several balloons of increasing diameter were used and each inflated two or three times. Cinefilm was taken to confirm full inflation of the balloon and loss of indentation by the stenotic valve.

After each inflation and at the end of the procedure, when the patient's haemodynamic state was stable, simultaneous left ventricular and aortic pressures were recorded. Aortography was not routinely repeated. The arterial sheath was removed, and haemostasis was achieved by pressure.

In one patient (a 70 year old woman with diabetes and peripheral arterial disease) dilatation was performed by a trans-septal approach through the right femoral vein.

Patients were admitted to the coronary care unit for

Correspondence to:

Dr Jackson. 
observation for 24 hours and then transferred to a general ward.

Echocardiography and Doppler study were carried out with a standard Hewlett Packard system with a $2.5 \mathrm{MHz}$ duplex transducer for echocardiographic imaging and pulsed wave Doppler studies and a 1.9 $\mathrm{MHz}$ transducer for continuous wave Doppler studies. A full study was performed from all conventional views. The peak aortic pressure gradient was calculated from the simplified Bernoulli equation (peak aortic gradient $(\mathrm{mm} \mathrm{Hg})=4 \times$ peak aortic velocity ${ }^{2}$ $(\mathrm{m} / \mathrm{s})) .^{1213}$

The area of the aortic valve was calculated by a modification of the continuity equation (area of aortic valve $=$ subaortic area $\times$ peak subaortic velocity/peak aortic velocity); this method has been validated against measurement of the area of the valve by the Gorlin formula. ${ }^{14-17}$ To measure the subaortic velocity the sample volume was placed in the left ventricular outflow tract in both the apical long axis view and the apical four chamber view, and the maximum velocity was taken. Subaortic area was calculated from the subaortic diameter just below the aortic valve (from the leading edge of the left septal border to the leading edge of the anterior mitral leaflet) on freeze frame images recorded in the parasternal long axis view in early systole (subaortic area $\left.=(\text { diameter } / 2)^{2} \times \pi\right)$. Echocardiography was performed before the valve was dilated and again before the patient was discharged. When possible further studies were made at intervals of three months during follow up. Echocardiographic and Doppler measurements were made from prints by one observer (DCS).

Patients were questioned about their symptoms and effort tolerance before and one month after operation.

TABLE I-Clinical characteristics of patients selected for balloon dilatation of aortic valve

\begin{tabular}{|c|c|c|c|c|}
\hline $\begin{array}{l}\text { Case } \\
\text { No }\end{array}$ & $\begin{array}{c}\text { Age } \\
\text { (years) }\end{array}$ & Sex & $\begin{array}{c}\text { Functional } \\
\text { class }^{\star}\end{array}$ & Other disease \\
\hline 1 & 70 & F & IV & Rheumatoid arthritis \\
\hline 2 & 81 & $\mathbf{M}$ & III & \\
\hline 3 & 73 & $\mathbf{F}$ & IV & $\begin{array}{l}\text { Chronic airways obstruction, lung } \\
\text { resection }\end{array}$ \\
\hline 4 & 76 & F & IV & \\
\hline 5 & 73 & M & III & Chronic airways obstruction \\
\hline 6 & 77 & $\mathbf{F}$ & III & Polymyalgia rheumatica \\
\hline 7 & 68 & $\mathrm{~F}$ & IV & Coronary artery disease of one vessel $\dagger$ \\
\hline 8 & 73 & $\mathrm{M}$ & III & Bronchial carcinoma \\
\hline 9 & 67 & $\mathbf{F}$ & II & Chronic airways obstruction \\
\hline 10 & 84 & $\mathrm{~F}$ & III & Coronary artery disease of one vessel $\downarrow$ \\
\hline 11 & 82 & $\mathbf{M}$ & II & \\
\hline 12 & 83 & $\mathbf{F}$ & III & Coronary artery disease of two vessels $\dagger$ \\
\hline 13 & 76 & $\mathbf{F}$ & II & \\
\hline 14 & 72 & $\mathbf{M}$ & III & Chronic airways obstruction \\
\hline 15 & 75 & $\mathbf{M}$ & III & Chronic airways obstruction \\
\hline 16 & 79 & $\mathbf{M}$ & III & $\begin{array}{l}\text { Coronary artery disease of two vessels, } \uparrow \\
\text { myocardial infarction }\end{array}$ \\
\hline 17 & 80 & $\mathbf{F}$ & IV & Mitral regurgitation \\
\hline 18 & 68 & $\mathbf{F}$ & III & $\begin{array}{l}\text { Hypothyroidism; coronary artery } \\
\text { disease of three vessels } \nmid\end{array}$ \\
\hline 19 & 83 & $M$ & IV & $\begin{array}{l}\text { Diabetes mellitus, coronary artery } \\
\text { disease of one vessel, } \dagger \text { myocardial } \\
\text { infarction, chronic airways } \\
\text { obstruction }\end{array}$ \\
\hline 20 & 86 & $\mathbf{F}$ & III & Mitral regurgitation \\
\hline 21 & 65 & $M$ & II & $\begin{array}{l}\text { Chronic airways obstruction, coronary } \\
\text { artery disease of one vessel } \dagger\end{array}$ \\
\hline 22 & 77 & $M$ & II & Colonic carcinoma \\
\hline 23 & 78 & $\mathbf{F}$ & III & $\begin{array}{l}\text { Diabetes mellitus, coronary artery } \\
\text { disease of one vessel, } \uparrow \text { myocardial } \\
\text { infarction, peripheral vascular } \\
\text { disease }\end{array}$ \\
\hline 24 & 73 & $M$ & III & \\
\hline 25 & 70 & $\mathrm{~F}$ & III & $\begin{array}{l}\text { Diabetes mellitus, coronary artery } \\
\text { disease of two vessels } f \text {, peripheral } \\
\text { vascular disease }\end{array}$ \\
\hline 26 & 78 & $\mathrm{~F}$ & III & \\
\hline 27 & 79 & M & III & \\
\hline 28 & 81 & $\mathbf{F}$ & III & Colonic angiodysplasia \\
\hline 29 & 83 & $\mathbf{F}$ & IV & Chronic osteomyelitis \\
\hline 30 & 85 & $\mathbf{F}$ & IV & \\
\hline 31 & 78 & $\mathbf{F}$ & II & Coronary artery disease of one vessel $\dagger$ \\
\hline 32 & 67 & $M$ & II & Chronic airways obstruction \\
\hline
\end{tabular}

«New York Heart Association's classification."

†Reduction of $>70 \%$ in luminal diameter of major vessel.
TABLE II-Pressures before and after dilatation ( $\mathrm{mm} \mathrm{Hg}$ )

\begin{tabular}{|c|c|c|c|c|c|c|c|}
\hline \multirow{2}{*}{$\begin{array}{c}\text { Case } \\
\text { No }\end{array}$} & \multicolumn{2}{|c|}{$\begin{array}{c}\text { Left } \\
\text { ventricular } \\
\text { peak systolic } \\
\text { pressure }\end{array}$} & \multicolumn{2}{|c|}{$\begin{array}{l}\text { Aortic peak } \\
\text { systolic } \\
\text { pressure }\end{array}$} & \multicolumn{2}{|c|}{$\begin{array}{l}\text { Peak to peak } \\
\text { gradient }\end{array}$} & \multirow{2}{*}{$\begin{array}{l}\text { Diameter of } \\
\text { balloons (mm) }\end{array}$} \\
\hline & Before & After & Before & After & Before & After & \\
\hline 1 & 180 & 160 & 112 & 120 & 68 & 40 & 8,12 \\
\hline 2 & 224 & 210 & 118 & 118 & 106 & 92 & $8,10,12$ \\
\hline 3 & 230 & 130 & 114 & 76 & 116 & 54 & $4,8,10$ \\
\hline 4 & 222 & 222 & 132 & 144 & 90 & 78 & 8,10 \\
\hline 5 & 158 & 154 & 74 & 80 & 84 & 74 & 10 \\
\hline 6 & 178 & 138 & 128 & 90 & 50 & 48 & $8,10,12,15$ \\
\hline 7 & 194 & 158 & 120 & 104 & 74 & 54 & 12 \\
\hline 8 & 178 & 136 & 150 & 114 & 28 & 22 & 8,15 \\
\hline 9 & 232 & 232 & 156 & 188 & 76 & 44 & 8 \\
\hline 10 & 178 & 164 & 128 & 106 & 50 & 58 & 10 \\
\hline 11 & 196 & 190 & 136 & 146 & 60 & 44 & 20 \\
\hline 12 & 268 & 182 & 188 & 118 & 80 & 64 & $10,15,20$ \\
\hline 13 & 230 & 122 & 180 & 104 & 50 & 18 & 20 \\
\hline 14 & 204 & 176 & 146 & 134 & 58 & 42 & 18,20 \\
\hline 15 & 184 & 180 & 140 & 156 & 44 & 24 & 20 \\
\hline 16 & 218 & 216 & 128 & 136 & 90 & 80 & 15,20 \\
\hline 17 & 164 & 174 & 98 & 128 & 66 & 46 & 10,20 \\
\hline 18 & 204 & 152 & 148 & 104 & 56 & 48 & 20 \\
\hline 19 & 166 & 146 & 136 & 120 & 32 & 26 & 10,18 \\
\hline 20 & 150 & 154 & 130 & 126 & 20 & 28 & 10 \\
\hline 21 & 202 & 178 & 132 & 112 & 70 & 66 & $10+10,10+10^{\star}$ \\
\hline 22 & 232 & 154 & 150 & 108 & 82 & 46 & 20 \\
\hline 23 & 188 & 212 & 140 & 190 & 48 & 22 & 10 \\
\hline 24 & 166 & 150 & 102 & 110 & 64 & 40 & 20 \\
\hline 25 & 134 & 138 & 110 & 126 & 24 & 12 & 10,20 \\
\hline 26 & 238 & 226 & 136 & 176 & 102 & 50 & 15,20 \\
\hline 27 & 154 & 174 & 124 & 164 & 30 & 10 & 10,20 \\
\hline 28 & 202 & 178 & 138 & 128 & 64 & 50 & $10,19,20$ \\
\hline 29 & 178 & 140 & 102 & 110 & 76 & 30 & 20 \\
\hline 30 & 208 & 164 & 110 & 122 & 98 & 42 & 20 \\
\hline 31 & 258 & 238 & 198 & 188 & 60 & 50 & 20 \\
\hline 32 & 208 & 244 & 144 & 170 & 64 & 74 & 20 \\
\hline $\begin{array}{l}\text { Mean } \\
\text { SD }\end{array}$ & $\begin{array}{r}198 \\
32\end{array}$ & $\begin{array}{r}175 \\
34\end{array}$ & $\begin{array}{r}133 \\
26\end{array}$ & $\begin{array}{r}129 \\
30\end{array}$ & $\begin{array}{l}65 \\
24\end{array}$ & $\begin{array}{l}46 \\
20\end{array}$ & \\
\hline
\end{tabular}

$\star$ Two balloons were used in this patient.

Their functional state was determined on 31 January 1988. Patients referred from other hospitals were contacted by telephone, or information about them was obtained from their doctor.

Measurements before and after dilatation were compared by Student's $t$ test for paired data. The estimated one year survival rate and its standard error were calculated by the method of Cutler and Ederer. ${ }^{18}$ The $\chi^{2}$ test was used to compare categorical variables in the patients who survived during follow up and those who died.

\section{Results}

Balloon dilatation of the aortic valve was performed on 32 patients between 31 January 1986 and 14 August 1987. Table I gives clinical characteristics of the patients. Their mean age was 76 (SD 6) years (range 6586). Seven were in the New York Heart Association's functional class II, 17 in class III, and eight in class IV. Eleven had been referred from other hospitals.

The catheter balloon was satisfactorily placed in all patients. One to four balloons were used in each. The largest balloon used was $20 \mathrm{~mm}$ in diameter for 19 patients (including one patient in whom a dual balloon technique with 10 and $15 \mathrm{~mm}$ balloons was used) and $8-18 \mathrm{~mm}$ in diameter in 13. Cineangiography during inflation showed complete inflation and loss of the indentation by the stenotic valve in all cases.

Table II gives data on pressures before and after dilatation. Left ventricular systolic pressure fell from 198 (32) $\mathrm{mm} \mathrm{Hg}$ to 175 (34) $\mathrm{mm} \mathrm{Hg}$ after dilatation $(\mathrm{p}<0.001)$. Aortic systolic pressure did not change significantly (133 (26) mm Hg before and 129 (30) $\mathrm{mm} \mathrm{Hg}$ after dilatation; $\mathrm{p}=0.54)$. The peak to peak gradient was reduced from 65 (24) $\mathrm{mm} \mathrm{Hg}$ to 46 (20) $\mathrm{mm} \mathrm{Hg}(\mathrm{p}<0.001)$. Aortography was repeated in eight patients; it showed no change in the degree of aortic regurgitation in seven and a slight increase (from $1+$ to $2+)$ in one. The procedure (including left heart 
catheterisàtion) took 104 (41) minutes, and screening time was 23 (15) minutes.

Major complications occurred in four patients, three of whom developed cardiac tamponade during or shortly after the procedure. In several patients the balloon had been seen to oscillate to and fro in the ventricle during inflation before it locked in the valve; presumably this movement drove the tip of the guide wire through the wall of the ventricle. In all cases tamponade was successfully treated by pericardiocentesis. One patient (a 73 year old woman who was in cardiogenic shock before dilatation) died four hours after the procedure after cardiac arrest; echocardiography had not shown recurrence of tamponade. The two other patients made uncomplicated recoveries.

Dissection of the femoral artery occurred in an 83 year old woman who presented in cardiogenic shock; because of the urgency the standard protocol of progressive dilatation of the femoral artery was not followed. Though the dissection was successfully repaired at operation, she remained in low output heart failure and died four days later.

Two patients developed haematomas in the groin but did not require operation. No patient sustained a stroke, and no embolisms were seen.

Table III shows the results of Doppler echocardiography. Recordings of aortic velocity were obtained

TABLE III-Doppler and aortographic measurements before and after dilatation

\begin{tabular}{|c|c|c|c|c|c|c|}
\hline \multirow[b]{2}{*}{ Case No } & \multicolumn{2}{|c|}{$\begin{array}{c}\text { Peak aortic } \\
\text { velocity }(\mathbf{m} / \mathbf{s})\end{array}$} & \multicolumn{2}{|c|}{$\begin{array}{l}\text { Valve area } \\
\qquad\left(\mathrm{cm}^{2}\right)\end{array}$} & \multicolumn{2}{|c|}{$\begin{array}{l}\text { Grade of aortic } \\
\text { regurgitation }\end{array}$} \\
\hline & Before & After & Before & After & Before & After \\
\hline $\begin{array}{r}1 \\
2 \\
3 \\
4 \\
5 \\
6 \\
7 \\
8 \\
9 \\
10 \\
11 \\
12 \\
13 \\
14 \\
15 \\
16 \\
17 \\
18 \\
19 \\
20 \\
21 \\
22 \\
23 \\
24 \\
25 \\
26 \\
27 \\
28 \\
29 \\
30\end{array}$ & $\begin{array}{l}4 \cdot 5 \\
5 \cdot 0 \\
4 \cdot 8 \\
5 \cdot 6 \\
3 \cdot 9 \\
4 \cdot 1 \\
4 \cdot 8 \\
3 \cdot 0 \\
4 \cdot 0 \\
4 \cdot 0 \\
4 \cdot 6 \\
4 \cdot 8 \\
4 \cdot 7 \\
4 \cdot 7 \\
3 \cdot 6 \\
3.9 \\
4 \cdot 5 \\
4 \cdot 5 \\
2 \cdot 5 \\
3 \cdot 3 \\
4 \cdot 5 \\
3 \cdot 5 \\
3 \cdot 6 \\
3.9 \\
2 \cdot 8 \\
4 \cdot 9 \\
2 \cdot 5 \\
4 \cdot 7 \\
\text { NA } \\
5 \cdot 0 \\
3 \cdot 9 \\
4 \cdot 9\end{array}$ & $\begin{array}{l}3.2 \\
5.0 \\
\text { NA } \\
5.3 \\
3.7 \\
2.7 \\
4.6 \\
2.9 \\
4.6 \\
\text { NA } \\
4.0 \\
5.0 \\
4.9 \\
4.8 \\
3.5 \\
\text { NA } \\
3.8 \\
4.4 \\
2.7 \\
3.3 \\
3.9 \\
2.9 \\
\text { NA } \\
3.1 \\
2.9 \\
4.7 \\
3.2 \\
4.0 \\
2.5 \\
3.4 \\
4.0 \\
4.0\end{array}$ & $\begin{array}{l}0.44 \\
\text { NA } \\
\text { NA } \\
0.43 \\
\text { NA } \\
\text { NA } \\
\text { NA } \\
\text { NA } \\
0.81 \\
\text { NA } \\
0.65 \\
0.34 \\
0.61 \\
0.62 \\
0.89 \\
\text { NA } \\
0.58 \\
\text { NA } \\
\text { NA } \\
0.54 \\
0.99 \\
0.58 \\
\text { NA } \\
0.61 \\
0.69 \\
0.57 \\
\text { NA } \\
0.53 \\
\text { NA } \\
\text { NA } \\
0.71 \\
0.43\end{array}$ & $\begin{array}{l}0.58 \\
\text { NA } \\
\text { NA } \\
0.45 \\
\text { NA } \\
\text { NA } \\
\text { NA } \\
\text { NA } \\
0.85 \\
\text { NA } \\
0.64 \\
0.33 \\
0.72 \\
0.60 \\
1.17 \\
\text { NA } \\
0.52 \\
\mathrm{NA} \\
\mathrm{NA} \\
0.84 \\
1.17 \\
0.73 \\
\mathrm{NA} \\
0.93 \\
0.88 \\
0.53 \\
\mathrm{NA} \\
0.73 \\
\mathrm{NA} \\
\mathrm{NA} \\
0.90 \\
0.55\end{array}$ & $\begin{array}{l}2+ \\
2+ \\
1+ \\
2+ \\
1+ \\
0 \\
2+ \\
1+ \\
1+ \\
2+ \\
1+ \\
1+ \\
2+ \\
2+ \\
2+ \\
1+ \\
2+ \\
0 \\
1+ \\
1+ \\
1+ \\
1+ \\
1+ \\
2+ \\
2+ \\
1+ \\
1+ \\
0 \\
\text { NA } \\
1+ \\
1+ \\
\text { NA }\end{array}$ & $\begin{array}{l}2+ \\
\text { NA } \\
\text { NA } \\
2+ \\
\text { NA } \\
0 \\
\text { NA } \\
\text { NA } \\
\text { NA } \\
\text { NA } \\
1+ \\
\text { NA } \\
\text { NA } \\
\text { NA } \\
\text { NA } \\
1+ \\
\text { NA } \\
\text { NA } \\
\text { NA } \\
2+ \\
1+ \\
\text { NA } \\
\text { NA } \\
\text { NA } \\
\text { NA } \\
\text { NA } \\
\text { NA } \\
\text { NA } \\
\text { NA } \\
\text { NA } \\
1+ \\
\text { NA }\end{array}$ \\
\hline
\end{tabular}

TABLE IV-Area of aortic valve $\left(\mathrm{cm}^{2}\right)$ before and after dilatation and at follow up (mean 23 weeks) in 11 patients

\begin{tabular}{cccc}
\hline $\begin{array}{c}\text { Case } \\
\text { No }\end{array}$ & Before & After & $\begin{array}{c}\text { At } \\
\text { follow up }\end{array}$ \\
\hline 1 & 0.44 & 0.58 & 0.52 \\
4 & 0.43 & 0.45 & 0.46 \\
9 & 0.81 & 0.85 & 0.69 \\
13 & 0.61 & 0.72 & 0.59 \\
14 & 0.62 & 0.60 & 0.83 \\
15 & 0.89 & 1.17 & 0.83 \\
25 & 0.69 & 0.88 & 0.85 \\
26 & 0.57 & 0.53 & 0.52 \\
28 & 0.53 & 0.73 & 0.58 \\
31 & 0.71 & 0.90 & 0.57 \\
32 & 0.43 & 0.55 & 0.52 \\
\hline Mean & 0.61 & 0.72 & 0.63 \\
SD & 0.15 & 0.21 & 0.14
\end{tabular}

both before and after dilatation of the valve (mean four days) in 28 patients. Peak aortic velocity fell from $4 \cdot 2$ $(0.8) \mathrm{m} / \mathrm{s}$ to $3.9(0.8) \mathrm{m} / \mathrm{s}(\mathrm{p}<0.05)$, representing a fall in the estimated peak instantaneous aortic gradient from 71 to $61 \mathrm{~mm} \mathrm{Hg}$.

The area of the aortic valve was assessed by Doppler echocardiography in 18 patients and increased from $0.61(0.16) \mathrm{cm}^{2}$ to $0.74(0.23) \mathrm{cm}^{2}(\mathrm{p}<0.001)$ (figure 1$)$. Dilatation had a variable effect on the area. In six patients the area changed by $\leqslant 10 \%$ and in 12 patients it increased by $16-56 \%$, becoming $>0.7 \mathrm{~cm}^{2}$ in 11 patients but $>1.0 \mathrm{~cm}^{2}$ in only two. In 11 of 18 patients the area of the valve was measured again six to 50 (mean 23) weeks after dilatation (table IV; figure 2 ). The mean area had increased from $0.61(0.15) \mathrm{cm}^{2}$ to 0.72

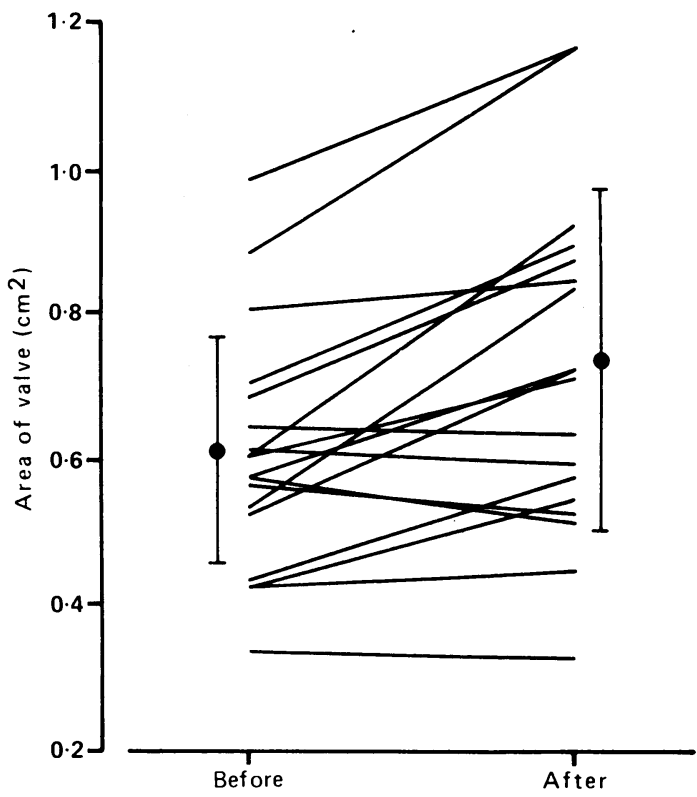

FIG 1-Area of aortic valve (measured by Doppler echocardiography) before and 1-7 (mean 4) days after dilatation in 18 patients. Vertical bars indicate mean $(S D)$

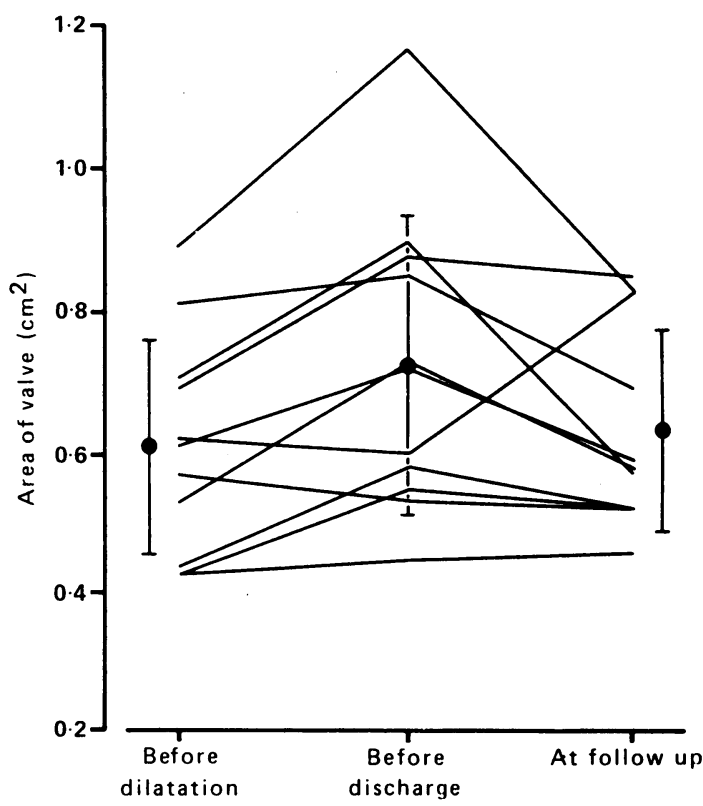

FIG 2-Area of aortic valve before dilatation, before discharge (1-7 days after operation), and at follow up (6-50 (mean 23) weeks after dilatation) in 11 patients. Vertical bars indicate mean (SD)

$(0.21) \mathrm{cm}^{2}$ before discharge but fell to $0.63(0 \cdot 14) \mathrm{cm}^{2}$ at follow up. In seven patients the area was less than before dilatation. The mean area at follow up did not differ significantly from that before dilatation $(p=0.6)$.

Among the 29 patients alive one month after the procedure symptoms had improved in 17, were unchanged in 11, and were worse in one. Four patients in whom the area of the valve changed by $\leqslant 10 \%$ reported an improvement in symptoms. Among the 12 patients in whom the area of the valve increased, symptoms were improved in six, unchanged in five, and worse in one.

Symptoms recurred or worsened in most patients during follow up, and the mortality of the group was high. On 31 January 1988, 16 patients were alive; the mean duration of follow up was 10 months (range 324). Two patients had had the aortic valve replaced and four were awaiting operations. Only two of the remaining 10 patients had lasting clinical benefit from balloon dilatation. A 73 year old man, previously in the New York Heart Association's class III, had an unlimited effort tolerance after eight months; the area of the valve 
had increased from 0.61 to $0.93 \mathrm{~cm}^{2}$ after dilatation. A 76 year old woman had improved effort tolerance after 13 months, though she was still in the New York Heart Association's class II; the area of the valve had increased from 0.61 to $0.72 \mathrm{~cm}^{2}$ after dilatation but had fallen to $0.59 \mathrm{~cm}^{2}$ at eight months. Neither was willing to undergo valve replacement.

Sixteen patients died (table V). The estimated one year survival rate was $49 \%$ ( $\mathrm{SE}=0 \cdot 1015,95 \%$ confidence interval $29 \%$ to $69 \%$ ). Death was attributable to a cardiac cause in 12 patients (including three who died suddenly). Patients who died did not differ from those who survived in mean age (76 (6) years in both groups), but a greater proportion who died were in the New York Heart Association's class III or IV before dilatation $\left(15 / 16 v 10 / 16\right.$ who survived; $\chi^{2}=2 \cdot 9, \mathrm{df}=2, \mathrm{p}=$ 0.08 ) or had a blood urea concentration $>10 \mathrm{mmol} / \mathrm{l}$ $\left(13 / 16 v 4 / 16 ; \chi^{2}=8 \cdot 0, \mathrm{df}=2, \mathrm{p}=0.005\right)$.

TABLE V - Causes of death after dilatation

\begin{tabular}{rcl}
\hline Case No & No of months survived & \multicolumn{1}{c}{ Cause of death } \\
\hline 3 & 0 & Cardiac arrest \\
29 & 0 & Heart failure \\
17 & 0 & Heart failure \\
19 & 2 & Gastrointestinal haemorrhage \\
27 & 3 & Heart failure \\
16 & 3 & Heart failure \\
25 & 3 & Not established \\
5 & 4 & Sudden death (cardiac cause) \\
23 & 4 & Cardiac arrest \\
20 & 4 & Not established \\
8 & 6 & Bronchial carcinoma \\
4 & 7 & Heart failure \\
1 & 9 & Heart failure \\
12 & 12 & Sudden death (cardiac cause) \\
9 & 13 & Sudden death (cardiac cause) \\
7 & 13 & Myocardial infarction
\end{tabular}

*Necropsy performed

\section{Discussion}

Our results show that balloon dilatation of the aortic valve achieved only a modest, variable, and temporary improvement in valve function in elderly patients who had severe calcific aortic stenosis. Degenerative calcific disease is probably the commonest cause of aortic stenosis in this age group. ${ }^{19-21}$ The area of the valve is reduced because rigidity of the cusps (due to calcium deposits) prevents full opening. In contrast with rheumatic or congenital valvular stenosis, commissural fusion is absent or unimportant; thus one of the principal mechanisms of balloon dilatation, the splitting of fused commissures, cannot operate. Necropsy and intraoperative studies have shown that balloon inflation may fracture nodular calcific deposits and stretch cusp tissue, ${ }^{22}$ although the extent to which the area of the valve is increased is disputed..$^{23}$

Other workers have obtained greater increases in the area of the valve in populations that closely resembled ours; they used a similar proportion of catheter balloons of $20 \mathrm{~mm}$ diameter. ${ }^{6-10}$ In the largest series from a single centre Cribier et al reported an increase in the area of the valve from 0.49 to $0.93 \mathrm{~cm}^{2}$ in 92 patients; the resultant area was $>0.7 \mathrm{~cm}^{2}$ in $79 \%$ and $>1.0 \mathrm{~cm}^{2}$ in $32 \%$ of patients. ${ }^{7}$ The French registry of 507 patients undergoing valvar dilatation in 27 centres, however, reported a resultant area of $>0.7 \mathrm{~cm}^{2}$ in only $55 \%$ of patients. ${ }^{25}$

Restenosis after dilatation may reflect the "healing" of fractures in calcific nodules, stretched cusp tissue resuming its former shape, or (as degenerative calcific aortic stenosis is progressive ${ }^{26}$ ) further deposition of calcium in the cusps. The high incidence of restenosis that we observed differs appreciably from the incidence found in previous studies. McKay et al reported that measurement of aortic cusp excursion on $M$ mode echocardiography six weeks after dilatation of the aortic valve showed no evidence of restenosis in 17 of 32 patients. ${ }^{6}$ This method of assessing valve function in aortic stenosis has important limitations. ${ }^{27}$ Cribier et al catheterised 12 of 92 patients between four and 24 weeks (mean 14) after dilatation and found that the reduction in peak to peak gradient had been maintained; measurement of the area of the valve by the Gorlin formula in 10 patients showed no evidence of restenosis (mean area $0.76 \mathrm{~cm}^{2}$ immediately after dilatation and $0.75 \mathrm{~cm}^{2}$ after reinsertion of the catheter). ${ }^{7}$ Clinical information was not given about this small subset of patients, who may not have been representative.

Most of our patients reported an improvement in symptoms and effort tolerance one month after dilatation. Progression or treatment of accompanying cardiac or non-cardiac disease, both of which were common in our patients, may have accounted for the lack of a relation between this response of symptoms and the effect of dilatation on the area of the valve. In addition, patients' reporting of symptoms may have been influenced by their expectations of a new form of treatment. The limitations of a history in assessing effort tolerance are recognised, ${ }^{28}{ }^{29}$ and a suitable objective measurement (such as the distance walked in six minutes ${ }^{30}$ ) would be preferable for future studies.

The management of patients whose symptoms recur or worsen after balloon dilatation is difficult. Dilatation was repeated (without complication) in six patients, all of whom were in the New York Heart Association's class III or IV. The interval between procedures ranged from three to 12 (mean six) months. The mean area of the valve increased slightly but not significantly (from $0.61(0.22)$ to $\left.0.68(0.23) \mathrm{cm}^{2}\right)$. Symptoms improved in only one patient.

Even though our patients were elderly and many had other disease, unrelieved aortic stenosis probably made an important contribution to the high mortality seen during follow up. The poor prognosis of symptomatic aortic stenosis is well recognised. ${ }^{31-33}$ The area of the valve was less than $0.7 \mathrm{~cm}^{2}$ (that is, in the range defined as severe stenosis) in seven of 18 patients shortly after dilatation and in eight of 11 at follow up. Unless dilatation can consistently create an orifice with an area comparable with that of a prosthetic aortic valve (in most cases $1 \cdot 0-1.5 \mathrm{~cm}^{2}$ or more $)^{34-37}$ it is unlikely to confer the improved life expectancy that follows successful valve replacement. ${ }^{2}$ This cannot be achieved at present, and we therefore believe that valve dilatation should be used only for patients with severe symptoms in whom life expectancy is limited by other disease. Dilatation may have a place in the management of patients with aortic stenosis who present with cardiogenic shock or severe pulmonary oedema. The high mortality after emergency operations to replace aortic valves in the elderly ${ }^{3}$ might be reduced if left ventricular function could be improved before operation.

We thank the nursing staff of the catheter laboratory and acute cardiac ward and Marilyn Moore, superintendent radiographer, for skilled help. DCS is funded by a donation to the cardiac department from Mr Kerry Packer. JBC holds a British Heart Foundation junior fellowship.

1 Lombard JT, Selzer A. Valvular aortic stenosis. A clinical and hemodynamic profile of patients. Ann Intern Med 1987;106:292-8.

2 Craver JM, Goldstein J, Jones EL, Knapp WA, Hatcher CR Jr. Clinical, hemodynamic, and operative descriptors affecting outcome of aortic valve replacement in elderly versus young patients. Ann Surg 1984;199:733-40.

3 Magovern JA, Pennock JL, Campbell DG, et al. Aortic valve replacement and combined aortic valve replacement and coronary artery bypass grafting: predicting high risk groups. $f$ Am Coll Cardiol 1987;9:38-43.

4 Cribier A, Savin T, Saoudi N, Rocha P, Berland J, Letac B. Percutaneous transluminal valvuloplasty of acquired aortic stenosis in elderly patients: an alternative to valve replacement? Lancet 1986 ; $1: 63-7$.

5 Jackson G, Thomas S, Monaghan M, Forsyth A, Jewitt D. Inoperable aortic stenosis in the elderly: benefit from percutaneous valvuloplasty. $\mathrm{Br} \mathrm{Med} \mathcal{J}$ 1987;294:83-6. 
6 McKay RG, Safian RD, Lock JE, et al. Assessment of left ventricular and aortic valve function after aortic balloon valvuloplasty in adult patients with critical aortic stenosis. Circulation 1987;75:192-203.

7 Cribier A, Savin T, Berland J, et al. Percutaneous transluminal balloon valvuloplasty of adult aortic stenosis: report of 92 cases. $\mathcal{f} \mathrm{Am}$ Coll Cardiol 1987;9:381-8.

8 Drobinski G, Lechat P, Metzger JP, Lepailleur C, Vacheron A, Grosgogeat Y Results of percutaneous catheter valvuloplasty for calcified aortic stenosis in the elderly. Eur Heart $f$ 1987:8:322-8.

9 Isner JM, Salem DN, Desnoyers MR, et al. Treatment of calcific aortic stenosis by balloon valvuloplasty. $A m \mathcal{F}$ Cardiol 1987;59:313-7.

10 Schneider JF, Wilson M, Gallant TE. Percutaneous balloon aortic valvuloplasty for aortic stenosis in elderly patients at high risk for surgery. Ann Intern Med 1987;106:696-9.

11 Criteria Committee, New York Heart Association. Diseases of the heart and blood vessels: nomenclature and criteria for diagnosis. 6th ed. Boston: Little, Brown, 1964.

12 Judkins MP. Selective coronary arteriography. Part I: a percutaneous transfemoral technic. Radiology 1967;89:815-24.

13 Hatle L, Angelsen BA, Tromsdal A. Noninvasive assessment of aortic stenosi by Doppler ultrasound. Br Heart $\mathcal{F}$ 1980;43:284-92.

14 Currie PJ, Seward JB, Reeder GS, et al . Continuous-wave Doppler echocardiographic assessment of severity of calcific aortic stenosis: a simultaneous Doppler-catheter correlative study in 100 adult patients. Circulation 1985;71:1162-9.

15 Skjaerpe T, Hegrenaes L, Hatle L. Noninvasive estimation of valve area in patients with aortic stenosis by Doppler ultrasound and two-dimensional patients with aortic stenosis by Doppler u-8.

16 Zoghbi WA, Farmer KL, Soto JG, Nelson JG, Quinones MA. Accurate noninvasive quantification of stenotic aortic valve area by Doppler echocardiography. Circulation 1986;73:452.9.

17 Otto CM, Pearlman AS, Janko CL, Kraft CD, Fujioka MC. Simplification of the Doppler continuity equation for calculating stenotic aortic valve area [Abstract]. $\mathcal{F}$ Am Coll Cardiol 1987;9:236A.

18 Come PC, Riley MF, McKay RG, Safian R. Echocardiographic assessment of aortic valve area in elderly patients with aortic stenosis and of changes in valve area after percutaneous balloon valvuloplasty. $\mathcal{F} \mathrm{Am}$ Coll Cardio 1987;10:115-24.

19 Cutler SJ, Ederer F. Maximum utilization of the life table method in analyzing survival. $\mathcal{F}$ Chronic Dis 1958;8:699-712.

20 Roberts WC, Perloff JK, Constantino T. Severe valvutar aortic stenosis in patients over 65 years of age: a clinicopathologic study. Am $\mathcal{J}$ Cardiol 1971;27:497-506.

21 Pomerance A. Pathogenesis of aortic stenosis and its relation to age. Br Heart 1972;34:569-74.
22 Selzer A. Changing aspects of the natural history of valvular aortic stenosis. $N$ Engl f Med 1987;317:91-8.

23 Safian RD, Mandell VS, Thurer RE, et al. Postmortem and intraoperative balloon valvuloplasty of calcific aortic stenosis in elderly patients: mechanisms of successful dilation. $f$ Am Coll Cardiol 1987;9:655-60.

24 Robicsék F, Harbold NB Jr. Limited value of balloon dilatation in calcified aortic stenosis in adults: direct observations during open heart surgery. $A m \mathcal{F}$ Cardiol 1987;60:857-64.

25 Commeau P, Grollier G, Lamy E, et al. Percutaneous balloon dilatation of calcific aortic valve stenosis: anatomical and haemodynamic evaluation. Br Hearl f 1988;59:227-38.

26 Berland J, Cribier A, Savin T, Letac B. Does the severity of aortic stenosis influence results of balloon valvuloplasty [Abstract]. Circulation 1987;76 (suppl IV):76.

27 Wagner S, Selzer A. Patterns of progression of aortic stenosis: a longitudinal hemodynamic study. Circulation 1982;65:709-12.

28 Chang S, Clements S, Chang J. Aortic stenosis: echocardiographic cusp separation and surgical description of aortic valve in 22 patients. $A m \mathcal{F}$ Cardiol 1977;39:499-504.

29 Goldman L, Hashimoto B, Cook EF, Loscalzo A. Comparative reproducibility and validity of systems for assessing cardiovascular functional class: advantages of anew specific activity scale. Circulation 1981;64:1227-34.

30 Nylander E, Ekman I, Marklund T, Sinnerstad B, Karlsson E, Wranne B Severe aortic stenosis in elderly patients. Br Heart $\mathcal{F}$ 1986;55:480-7.

31 Lipkin DP, Scriven AJ, Crake T, Poole-Wilson PA. Six minute walking test for assessing exercise capacity in patients with chronic heart failure. Br Med f 1986;292:653-5.

32 Ross J Jr, Braunwald E. Aortic stenosis. Circulation 1968;38 (suppl 5):V. 61-7. 33 Chizner MA, Pearle DL, de Leon AC Jr. The natural history of aortic stenosis in adults. Am Heart $\mathcal{O}$ 1980;99:419-24.

34 O'Keefe JH Jr, Vlietstra RE, Holmes DR Jr, Bailey KR. Natural history of candidates for balloon aortic valvuloplasty. Mayo Clin Proc 1987;62:986-91.

35 Larmi TKI, Kairaluoma MI, Karkola P, Tuononen S, Nuutinen L. Intraoperative hemodynamic evaluation of the Björk-Shiley tilting disc aortic valve. I Thorac Cardiovasc Surg 1977;73:712-5.

36 Chaitman BR, Bonan R, Lepage G, et al. Hemodynamic evaluation of the Carpentier-Edwards porcine xenograft. Circulation 1979;60:1170-82.

37 Rothkopf M, Davidson T, Lipscomb K, et al. Hemodynamic evaluation of the Carpentier-Edwards bioprosthesis in the aortic position. Am $\mathcal{F}$ Cardio 1979;44:209-14.

38 Teoh KH, Fulop JC, Weisel RD, et al. Aortic valve replacement with a smal prosthesis. Circulation 1987;76 (suppl 3):III. 123-31.

(Accepted 14 fuly 1988 )
Department of Internal

Medicine, Central

Hospital, Hillerød,

Denmark

Asger Dirksen, DRMEDSCI, senior registrar

Department of Cardiology, State University Hospital, Copenhagen, Denmark

Erik Kiøller, DRMEDSCI, cardiologist

Correspondence and requests for reprints to: Dr A Dirksen, Noeddehoej 1, DK-2840 Holte, Denmark.

\title{
Cardiac predictors of death after non-cardiac surgery evaluated by intention to treat
}

\author{
Asger Dirksen, Erik Kjøller
}

\section{Abstract}

Cardiac risk factors were studied among patients who were admitted to hospital with appendicitis or a fracture of the proximal femur less than one year after being admitted with myocardial infarction. Of 99 patients with myocardial infarction and appendicitis, 87 underwent appendicectomy; and of 221 with myocardial infarction and hip fracture, 179 were operated on. The patients were studied on an intention to treat basis. The mortality within one month was $9 \%$ and $16 \%$ respectively. A history of congestive heart failure was the dominating risk factor, while ischaemic heart disease (recent myocardial infarction or angina pectoris) had no independent association with mortality.

If the ventricular function is known additional preoperative information about the heart is of negligible value when estimating the mortality of noncardiac surgery.

\section{Introduction}

Congestive heart failure and ischaemic heart disease are considered to be the most important predictors of death after non-cardiac surgery. ${ }^{12}$ Of the ischaemic heart diseases, a recent myocardial infarction is regarded as the most ominous condition, while an older infarction or angina pectoris is less important. ${ }^{3.5} \mathrm{~A}$ recent myocardial infarction is usually defined as one occurring within the preceding six months, and mortality after surgery is typically found to be 10 times higher in patients with recent infarction. ${ }^{4}$ Earlier studies did not take into account the possibility that awareness of risk factors may influence the selection of patients for operation. They were based on a broad range of diseases and many different surgical procedures, including elective operations. They also presented information only about patients who had been operated on-that is, they did not contain any data on patients who for various reasons (for example, recent myocardial infarction) were treated conservatively.

The purpose of the present study was to evaluate cardiac risk factors as predictors of operative death in an adequate number of patients with one specific disease who were all candidates for the same operation, thus minimising the variability associated with differences in disease and operation. We selected two acute conditions (appendicitis and hip fracture) that usually need urgent surgical treatment and analysed data according to the principle of intention to treat. Furthermore, to ensure a high frequency of cardiac risk factors in the study population we confined the study to patients who had suffered myocardial infarction in the year preceding the appendicitis or hip fracture.

\section{Patients and methods}

The national registry of hospitalised patients was established in Denmark in $1976 .^{6}$ The data provided by this registry include diagnoses and operations 